\title{
Management, Leadership, and Governance in Primary Education (Finland)
}

\author{
Varjo, Janne \\ Bloomsbury Publishing \\ 2019-11-19
}

Varjo , J 2019 , Management, Leadership, and Governance in Primary Education (Finland) . in J Kauko, I Menter \& M T Tatto (eds), Bloomsbury Education and Childhood Studies .

Bloomsbury Publishing , London . https://doi.org/10.5040/9781350996274.0027

http://hdl.handle.net/10138/314175

https://doi.org/10.5040/9781350996274.0027

acceptedVersion

Downloaded from Helda, University of Helsinki institutional repository.

This is an electronic reprint of the original article.

This reprint may differ from the original in pagination and typographic detail.

Please cite the original version. 


\section{Management, leadership and governance}

\section{Primary education (ISCED) 1}

Comprehensive school system, Local education authorities, Decentralization, 'Culture of trust', Pupil welfare staff

Comprehensive school system: An education system in which the schools are publicly funded and are commonly not able to select their intake on the basis of academic achievement or aptitude. It is the opposite of a selective school system, into which admission is based on selection criteria (Kalalahti, Silvennoinen, Varjo \& Rinne 2015).

Culture of trust: The unarticulated cultural principle in Finland, meaning that the central administration (Ministry of Education and Culture and the Finnish National Agency for Education) have confidence that local education authorities, together with principals, teachers, parents, and their communities know how to provide the best possible education for their children.

Municipality: An administrative division having corporate status and powers of self-government as granted by the national laws to which it is subordinate. In 2018, Finland consists of 311 municipalities. They are the main providers of basic education (Varjo \& Kalalahti 2018).

\section{Research on management, leadership and governance}

In Finland, local education administration at the primary level is the responsibility of the subordinate bodies of the state, municipalities. According Aho, Pitkänen and Sahlberg (2006), rather than unifying the education system through centralized decrees and standards, Finnish education policies have nurtured cohesive diversity and developed material and human resources. Hence, the practices on management, leadership and governance are distinctive.

The external supervision of work done in Finnish schools is minimal by international standards (EURYDICE 2004). Most 'traditional' forms of control over the teacher's work had disappeared by the beginning of the 1990s. The school inspectorate, a detailed national curriculum, officially approved teaching materials, weekly timetables based on the subjects taught and a class diary in which the teacher had to record what was taught each hour - all these traditional mechanisms were abandoned. Furthermore, Finland has never had a tradition of nationwide standardized testing at the primary school-level. (Simola 2015.)

Under these circumstances, the management, leadership and governance at the local level gains importance. Aho, Pitkänen and Sahlberg (2006; see also Simola, Kauko, Varjo, Kalalahti \& Sahlström 2017) emphasize the culture of trust. This principally means that the central administration (Ministry of Education and Culture and the Finnish National Agency for Education) have confidence that local education authorities, together with principals, teachers, parents, and their communities know how to provide the best possible education for their children.

\section{Structure}

Primary education in Finland refers to the first six years of basic, universal education in a nine-year comprehensive school system which is meant for children aged between seven and 16 years. Primary education is mainly public and is provided mainly by municipalities. Local education authorities make the decisions on the allocation of funding, local curricula and recruitment of personnel. The municipalities also have the autonomy to delegate decision-making power to the schools, if they see fit. (FNAE 2017.) 
The leadership structure and governance practices depend on the discretion of the education provider, and there is no legal basis for the solutions. The job descriptions and distribution of powers are recorded in the standing orders or rules of procedure approved by the local education authorities. Commonly, all schools have a principal and a vice principal, as well as one or more assistant principals as the school size increases. (Taipale 2012.) Additionally, various responsibility tasks have been delegated to pupil welfare staff (consists of school nurses, psychologists and welfare officers) and to the school secretary and janitors. The delegated tasks vary in different schools depending on the school size and administrative culture. (MoE 2007.)

\section{Administration}

According to Basic Education Act (Law 628/1998), municipalities have an obligation to arrange basic education for children of compulsory school age (7-16 years) residing in their area. Nevertheless, Local Government Act (Law 365/1995) give them considerable freedom to organize their administration as they see fit. This freedom is also exercised in practice and municipal organizations differ considerably from each other. For example, very small municipalities may comply with minimum legal requirements and have a limited government structure whereas larger municipalities may have a multi-faceted and complex governance and service delivery structure. (Björk, Kanervio \& Risku, 2014.)

Hence, municipalities are key operating environments for principals. According to Taipale (2012; see also Simola 2015) Finnish principals have a considerable autonomy within their schools. In general, a substantial amount powers have been delegated to principals and they are responsible for school development, human resources, school operations and operational effectiveness. Nevertheless, the distribution of powers and resources available vary by municipality. A distinctive Finnish characteristic is that small municipalities, in particular, have assigned principals external educational administration responsibilities above and beyond the school level mainly due to the shortage of financial resources. (Taipale 2012.)

\section{Leadership}

In Finland, the selection procedure of principals and teachers for municipal schools is determined in the municipal standing order. All posts are advertised for public application. Superiors select their own subordinates in many municipalities, with the exception of the highest-ranking officials, who are selected by the municipal council or board of education. There are no common regulations for a consultation procedure, but teaching staff and representatives of parents are often consulted when defining a new principal's competencies or also while comparing applicants for the post. Principals are initially appointed to their posts for a six-month trial period on a fixed-term basis. (Taipale 2012.) Private education providers may decide which of their bodies is responsible for appointing new principals and teachers.

School leaders, appointed by local educational authorities, are required to have a teacher qualification (up to a master's degree), a certificate in educational administration and teaching experience. There is no national regulation regarding participation in training for school leaders, which is the responsibility of municipalities. (OECD 2013.)

\section{Supervision}

Finland abandoned school inspections in the early 1990's, unlike the other Nordic countries (Simola et al. 2017). According to Basic Education Act (628/1998) education providers are responsible for evaluating the education and training that they provide and for participating in national or international evaluation work. Nevertheless, evaluation data about school operations and performance is collected regularly to support education policy decision-making. Comparative data on individual comprehensive schools is not made 
public. Education providers and schools use evaluation data in their development work. Schools have a selfevaluation obligation, while responsibility for external evaluations rests with education providers. (Taipale 2012.)

According to Simola et al. (2017) Finland has four distinctive features in terms of quality assurance and evaluation (QAE) of education. First, QAE data is targeted for administrative purposes only; second, the use of QAE data is restricted for administrative purposes only; third, there are no mandatory national tests for the whole age cohort; four, there are no school ranking lists publicly available.

\section{Challenges}

Decentralized decision-making system is evidently one of the major strengths in terms of management, leadership and governance. School leaders exercise a wide-ranging, independent decision-making power on issues concerning school development. It can be considered a considerable advantage that in terms of development work, education providers and schools are themselves responsible for their policies, for instance organization of instruction and school network solutions. This allows the best expertise and competence to be found locally, whilst the central administration has been able to concentrate on longterm strategic planning of educational policy and legislative development. (MoE 2007.)

Nevertheless, Simola et al. (2017) describe the culture of trust in the management, leadership and governance of Finnish primary education as a challenge, in particular because it is evident that current local autonomy impose demanding responsibilities on the municipalities - even to the extent that it is a problem in terms equal educational opportunities. How could the autonomy and freedom of municipalities and school principals be limited without destroying the culture of trust? (Simola 2015; Aho, Pitkänen \& Sahlberg 2006). It appears evident that a new kind of balance between centralized and decentralized management, leadership and governance is sought in Finnish basic education.

\section{References}

Aho, E., Pitkänen, K. and Sahlberg, P. (2006), Policy development and reform principles of basic and secondary education in Finland since 1968. The World Bank Education: Working Paper Series No. 2, Washington, DC: The World Bank.

EURYDICE (2004), Evaluation of Schools Providing Compulsory Education in Europe. No. D/2004/4008/2. European Commission, Directorate General for Education and Culture. Brussels: Eurydice, European Unit.

FNAE (2017), Finnish Education in a nutshell, Helsinki: The Finnish National Agency for Education, https://www.oph.fi/download/146428_Finnish_Education_in_a_Nutshell.pdf [accessed 22 November 2018].

Kalalahti, M., Silvennoinen, H., Varjo, J. and Rinne, R. (2015), 'Education for all? Urban parental attitudes towards universalism and selectivism in the Finnish comprehensive school system', in Seppänen, P., Carrasco, A., Kalalahti, M., Rinne, R. and Simola, H. (eds), Contrasting Dynamics in Education Politics of Extremes: school choice in Chile and Finland, Rotterdam: SensePublishers, 205-224.

Law 365/1995. Local Government Act.

Law 628/1998. Basic Education Act.

MoE. (2007), Improving School Leadership, Finland. Country Background Report. Publications of the Ministry of Education 2007:14, Helsinki: Ministry of Education. 
OECD. (2013), Education Policy Overview: Finland, Paris: Organization for Economic Co-operation and Development.

Risku, M., Kanervio, P. and Björk, L.G. (2014), 'Finnish Superintendents: Leading in a Changing Education Policy Context', Leadership and Policy in Schools, 13, 383-406.

Sahlberg, P. (2011), Finnish Lessons: What can the world learn from educational change in Finland? New York, NY: Teachers College Press.

Simola, H. (2015), The Finnish education mystery - Historical and sociological essays on Schooling in Finland, London: Routledge.

Simola, H., Kauko, J., Varjo, J., Kalalahti, M. and Sahlström, F. (2017), Dynamics in Education Politics Understanding and explaining the Finnish case, London: Routledge.

Taipale, A. (2012), International survey on educational leadership: A survey on school leader's work and continuing education. Publications 2012:12, Helsinki: The Finnish National Agency for Education.

Varjo, J. and Kalalahti, M. (2018), 'The art of governing local education markets - municipalities and school choice in Finland', Education Inquiry, Print ahead https://doi.org/10.1080/20004508.2018.1514907 [accessed 22 November 2018]. 